\section{Optimum Planting Dates for Intercropping Cucumber, Squash, and Muskmelon with Strawberry}

\author{
Bielinski M. Santos ${ }^{1,4}$, Camille E. Esmel ${ }^{2}$, Silvia Slamova², \\ and Elizabeth A. Golden ${ }^{3}$
}

AdDITIONAL INDEX WORDs. Fragaria $\times$ ananassa, Cucumis sativus, Cucurbita pepo, Cucumis melo, cucurbits, double-cropping, cultural practices, sustainable agriculture

\begin{abstract}
Summary. Three separate field trials were conducted to determine the most appropriate planting dates for intercropping cucumber (Cucumis sativus), summer squash (Cucurbita pepo), and muskmelon (Cucumis melo) with strawberry (Fragaria $\times$ ananassa), and their effect on 'Strawberry Festival' strawberry yields. 'Straight Eight' cucumber, 'Crookneck' summer squash, and 'Athena' muskmelon were planted every 15 days from 25 Jan. to 23 March. None of the three intercropped species affected strawberry yield up to 60 days before the end of the season on 25 March. Cucumber yield responded quadratically to planting dates, rapidly increasing from $25 \mathrm{Jan}$. to $23 \mathrm{Feb}$. and declining afterward. Warmer temperatures favored summer squash yield, with the highest yields when planted on $23 \mathrm{Feb}$. or later. Muskmelon yields decreased as air temperatures increased, and the best planting dates were between 25 Jan. and 9 Feb. In summary, cucumber and summer squash seemed to be favored by planting under warmer temperatures, whereas muskmelon thrives under cooler weather.
\end{abstract}

$\mathrm{T}$ The double-cropping and intercropping of vegetables has been increasingly investigated in recent years because of the enhanced interest in sustainable practices. Under double-cropping, a second crop is planted in the same production area previously used with a first crop to take advantage of residual fertilizers, mulch, and irrigation lines. Individual crop yields sometimes could decrease because of a lack of knowledge about cultural practices or because of environmental limitations (Brown et al., 1985). Relay intercropping overlaps production cycles of two crops in the same land. This method is used in tropical climates around the world because it allows increasing food diversity and security, especially in third-world countries (Theunissen, 1997). Interspecific competition for essential growing factors might occur in intercropped lands, where the first crop could have competitive advantage

Gulf Coast Research and Education Center, IFAS, University of Florida, 14625 County Road 672, Wimauma, FL 33598

${ }^{1}$ Assistant Professor of Horticulture.

${ }^{2}$ Research Assistant.

${ }^{3}$ Biological Scientist.

${ }^{4}$ Corresponding author. E-mail: bmsantos@ufl.edu. a major reason to conduct research to determine the competitive patterns of each species (Coolman and Hoyt, 1993).

Understanding the influence of a second crop on strawberry production is very important to a market valued at \$329 million (U.S. Department of Agriculture, 2008). Although market prices usually determine the length of the strawberry season, most growers agree that early yields provide the highest profits per unit, with prices generally declining at the end of February. A present trend among Florida strawberry growers is intercropping cucumber, summer squash, or muskmelon with strawberry. Reusing plastic mulches may increase cost-effectiveness while reducing environmental impact and the risk of economic failure during a year of lowmarket demand for a crop grown over a younger second crop. That is alone (Brown et al., 1985; Simms et al., 2006). It has been found that $60 \%$ of the costs of annual hill culture of strawberries can be recovered with the intercropping of muskmelons (Poling and Lamont, 1991). The majority of strawberry growers in Florida plant a second crop between 4 and 6 weeks before the end of the season, allowing growers to have earlier access to cucurbit markets in comparison with each crop planted separately (Duval, 2005).

An important issue for winter intercropping is the weather during January and February in Florida, when freezing temperatures regularly occur. There is a current tendency among growers to intercrop earlier than the last week in February. However, no research has been conducted to address that issue. Early cucurbit planting could expose young seedlings to unfavorable growing conditions. Temperature is a major factor in determining the time of pollen shed, flower opening and pollination, and growth rate in cucurbits, which in turn could influence yield and quality, if growing conditions were unfavorable (Sedgley and Buttrose, 1978; Wien, 2002). Sedgley and Buttrose (1978) indicated that temperatures between $77^{\circ} \mathrm{F}$ and $95^{\circ} \mathrm{F}$ favored flower numbers in watermelon (Citrullus lanatus), while higher temperatures decreased pollination. A summer squash study showed that low night temperatures $\left(46^{\circ} \mathrm{F}-50{ }^{\circ} \mathrm{F}\right)$ increase the number of noncommercial parthenocarpic fruit, whereas the opposite was observed with temperatures between $61{ }^{\circ} \mathrm{F}$ and $68^{\circ} \mathrm{F}$ (Rylski, 1974). Similar results were found by Nitsch et al. (1952) and Cantliffe (1981) when experimenting with other cucurbits.

With regard to intercropping, a previous study found a synergistic yield effect of strawberry intercropped with broad bean (Vicia faba) when fertilized with $80 \mathrm{~kg} \cdot \mathrm{ha}^{-1}$ nitrogen (Karlidag and Yildirim, 2007).

\begin{tabular}{llll}
\hline $\begin{array}{l}\text { Units } \\
\begin{array}{l}\text { To convert U.S. to SI, } \\
\text { multiply by }\end{array}\end{array}$ & U.S. unit & SI unit & $\begin{array}{l}\text { To convert SI to U.S., } \\
\text { multiply by }\end{array}$ \\
\hline 0.3048 & $\mathrm{ft}$ & $\mathrm{m}$ & 3.2808 \\
2.54 & inch $(\mathrm{es})$ & $\mathrm{cm}$ & 0.3937 \\
1.1209 & $\mathrm{lb} / \mathrm{acre}$ & $\mathrm{kg} \cdot \mathrm{ha}^{-1}$ & 0.8922 \\
2.2417 & ton/acre & $\mathrm{t} \cdot \mathrm{ha}^{-1}$ & 0.4461 \\
$\left({ }^{\circ} \mathrm{F}-32\right) \div 1.8$ & ${ }^{\circ} \mathrm{F}$ & ${ }^{\circ} \mathrm{C}$ & $\left(1.8 \times{ }^{\circ} \mathrm{C}\right)+32$
\end{tabular}


This is probably due to the effective combination of a nonleguminous crop with a legume. This is a popular intercropping combination in organic and sustainable agriculture. Another study showed that when cucumber, summer squash, and muskmelon are intercropped during the last week in February ( $31 \mathrm{~d}$ before the end of the strawberry season), strawberry yields are not reduced (Duval, 2005). The effect of different planting dates on the yield of the second crops was not addressed. Therefore, timing of direct seeding of the second crop into the first crop is a major component for intercropping to be successful in Florida. The objective of this study was to determine the most appropriate planting dates for cucumber, summer squash, and muskmelon intercropped with strawberry, and their effect on strawberry yields.

\section{Materials and methods}

Two field studies were conducted between Oct. 2005 and Mar. 2006, and Oct. 2006 and Mar. 2007 at the Gulf Coast Research and Education Center of the University of Florida in Balm. The soil was a sandy, siliceous, hyperthermic Oxyaquic Alorthod with $1.5 \%$ organic matter and a $\mathrm{pH}$ of 7.3. Strawberry fields were planted on 6 Oct. 2005 and 4 Oct. 2006 with bare-root transplants of 'Strawberry Festival' obtained from certified nurseries in southern Ontario, Canada. Planting beds were 28 inches wide at the base, 24 inches wide at the top, 10 inches high, and spaced $4 \mathrm{ft}$ apart on centers. Pressed beds were fumigated with methyl bromide plus chloropicrin $67: 33$, $\mathrm{v} / \mathrm{v}$ ) at a rate of $350 \mathrm{lb} /$ acre, fertilized with $50 \mathrm{lb} /$ acre of a $15 \mathrm{~N}-0 \mathrm{P}-24.9 \mathrm{~K}$ granular formula, and covered with black high-density polyethylene mulch. A single-drip irrigation line (T-Systems International, San Diego) was buried 1 inch deep on the bed center.

Plant nutrients and pest control were supplied following statewide recommendations (Peres et al., 2006). Drip-applied nitrogen and potassium were injected daily at rates of $0.6 \mathrm{lb} /$ acre [from transplanting to 5 weeks after transplanting (WAT)], $0.75 \mathrm{lb} /$ acre (from 6-9 WAT), and $1.0 \mathrm{lb} /$ acre (from 10-23 WAT) per day of each nutrient. Strawberry plots were $20 \mathrm{ft}$ long and plants were in double rows with 15 inches between plants. Overhead sprinkler irrigation was used for freeze protection. Each strawberry-cucurbit combination was planted in three separate experiments and each experiment consisted of two trials conducted in 2006 and 2007. Seeds of 'Straight Eight' cucumber, 'Crookneck' summer squash, and 'Athena' muskmelon were planted $15 \mathrm{~d}$ apart on 25 Jan., 9 Feb., 23 Feb., 9 Mar., and 23 March The latter planting date was the strawberry-free control for cucurbit yields because strawberry plants were removed from beds as the cucurbits were planted. Cucumber seeds were planted $\mathrm{l} \mathrm{ft}$ apart, while summer squash and muskmelon were established $2 \mathrm{ft}$ apart. All three species were seeded equidistant from each strawberry row.

In all three experiments, the treatments were distributed in a randomized complete block design with six replications. To determine the effect of the intercropped species, strawberry marketable yields were collected on each plot beginning on 25 Jan., regardless of the planting dates, until 23 March (16 harvests). Strawberry canopy diameter was measured on 23 March of each year, which corresponded to the latest intercropping date, across rows on five plants per plot during each cucurbit planting date to determine whether cucurbit planting dates affected strawberry aboveground biomass volume. Marketable fruits of cucumber and summer squash were collected six times, whereas muskmelon plots were harvested four times. Cucumber and summer squash plots were grown for $81 \mathrm{~d}$ and the first and last harvests occurred on 10 May and 14 June of each year, respectively. Muskmelon plots were produced for $97 \mathrm{~d}$ and the first and last harvests were on 1 and 30 June of each year, respectively. Data for each species were examined separately, and regression analysis was used to determine the significance $(P<0.05)$ of the relationship between planting dates and marketable yields of each crop (SAS version 9.1; SAS Institute, Cary, $\mathrm{NC})$. The regression equations were selected based on significance of the model $(P<0.05)$, high coefficient of determination values $\left(r^{2} \geq 0.80\right)$, and simplicity of the model (e.g., a quadratic model would be preferred over a cubic model). The resulting regression equations were solved to determine yield predicted values for each planting date, using $25 \mathrm{Jan}$. as day 0 and 23 March as day 60, and plotted using the actual planting dates on the $\mathrm{x}$-axis.

\section{Results and discussion}

There was no significant treatment by season interaction for any of the examined variables, thus data from the two seasons of each strawberry-cucurbit combination were pooled for analysis. The average, minimum, and maximum temperatures between January and June followed similar trends in 2006 and 2007, where the coldest month was February (Table 1). On 13 and 14 Feb. 2006 , there were freezing temperatures $\left(26^{\circ} \mathrm{F}\right.$ and $27^{\circ} \mathrm{F}$ for $4 \mathrm{~h}$ each day), and on 17 Feb. $2007\left(29^{\circ} \mathrm{F}\right.$ for $3 \mathrm{~h}$ ) and plants were protected with $10 \mathrm{~h}$ of overhead irrigation. These low temperatures occurred when only two cucurbit planting dates had been established (25 Jan. and 9 Feb.), and no strawberry or cucurbit plants were severely injured or lost. Average monthly temperatures surpassed $60{ }^{\circ} \mathrm{F}$ after Mar. 2006 and 2007, steadily increasing over time and reaching maximum temperatures above $90{ }^{\circ} \mathrm{F}$ after Apr. 2006 and 2007.

Cucurbit planting dates did not affect strawberry aboveground biomass volume as revealed by canopy diameters, which did not change significantly across planting dates, with average diameters of 15.2 and 15.3 inches during 2006 and 2007 , respectively (Table 2). This finding indicated that there was no effect of each cucurbit species on the architecture of established strawberry plants, regardless of planting dates. None of the three intercropped cucurbit species affected strawberry yield when planted between 25 Jan. and 23 Mar., when the strawberry season ended (Table 2). Average marketable strawberry yield for 16 harvests during that period was $\approx 9.2$ tons/acre, regardless of the cucurbit species and planting date. This confirms and expands previous results, indicating that the competition of these cucurbits against strawberry is negligible when strawberry plants are at least 15 weeks old (Duval, 2005).

Three significant quadratic regression equations described the 
Table 1. Average, minimum, and maximum air temperatures from January to June 2006 and 2007 during cucumber, summer squash, and muskmelon intercropping with strawberry at Balm, FL.

\begin{tabular}{|c|c|c|c|c|c|c|}
\hline \multirow[b]{3}{*}{ Month } & Avg & Minimum & Maximum & Avg & Minimum & Maximum \\
\hline & \multicolumn{3}{|c|}{2006} & \multicolumn{3}{|c|}{2007} \\
\hline & \multicolumn{6}{|c|}{ Air temp $\left({ }^{\circ} \mathbf{F}\right)^{\mathrm{z}}$} \\
\hline January & 61.6 & 29.7 & 85.0 & 63.1 & 33.7 & 86.0 \\
\hline February & 59.3 & 26.2 & 84.6 & 59.8 & 30.1 & 86.5 \\
\hline March & 65.8 & 33.6 & 87.8 & 67.0 & 37.8 & 86.2 \\
\hline April & 72.1 & 46.0 & 94.2 & 69.3 & 42.6 & 91.0 \\
\hline May & 75.5 & 52.3 & 95.6 & 75.2 & 52.4 & 94.4 \\
\hline June & 79.7 & 63.0 & 97.6 & 78.0 & 64.0 & 92.9 \\
\hline
\end{tabular}

${ }^{2}$ Temperatures measured at $1 \mathrm{ft}(0.3 \mathrm{~m})$ above soil level; $\left({ }^{\circ} \mathrm{F}-32\right) \div 1.8={ }^{\circ} \mathrm{C}$.

Table 2. Effects of cucumber, summer squash, and muskmelon planting dates on strawberry plant canopy diameter and marketable yield during the intercropping period at Balm, FL, in 2006 and $2007 .^{z}$

\begin{tabular}{lcc}
\hline $\begin{array}{l}\text { Planting } \\
\text { date }\end{array}$ & $\begin{array}{c}\text { Canopy } \\
\text { diameter } \\
\text { (inches) }^{\mathrm{y}}\end{array}$ & $\begin{array}{c}\text { Yield } \\
\text { (tons/acre) }\end{array}$ \\
\hline 25 Jan. & 15.2 & 9.3 \\
9 Feb. & 15.3 & 9.4 \\
23 Feb. & 15.3 & 9.1 \\
9 Mar. & 15.2 & 9.2 \\
23 Mar. & 15.2 & 9.3 \\
$\begin{array}{l}\text { Significance } \\
(P<0.05)\end{array}$ & $\mathrm{NS}^{\mathrm{x}}$ & $\mathrm{NS}$ \\
\hline
\end{tabular}

${ }^{\mathrm{z}}$ Strawberry marketable yield measured from the beginning of intercropping treatments ( $25 \mathrm{Jan}$.) to the date when strawberry plants were removed $(23$ Mar.). Strawberry data obtained from cucumber, summer squash, and muskmelon plots were averaged across cucurbit species because there was no significant species effect $(P>0.05)$ on strawberry canopy diameter and yield. Data were combined for two seasons and analyzed with general linear model procedure.

yl ton $/$ acre $=2.2417 \mathrm{t} \cdot \mathrm{ha}^{-1} ; \mathrm{l}$ inch $=2.54 \mathrm{~cm}$.

${ }^{\mathrm{x}} \mathrm{NS}=$ nonsignificant.

relationships between planting dates and cucurbit yields $\left(\mathrm{r}^{2} \geq 0.81\right)$. Cucumber yield significantly increased by $\approx 76 \%$ from 25 Jan. (6.2 tons/acre) to 23 Feb. (10.9 tons/acre) and declined afterward (Fig. 1). This finding suggested that cucumber performs best when planted around 23 Feb., allowing the crop to grow and set fruit during the cool part of the season (March and April) when average temperatures are below $75^{\circ} \mathrm{F}$ and maximum temperatures do not reach $95{ }^{\circ} \mathrm{F}$ (Table 1). Because plants established during early planting dates $(25$ Jan. and 9 Feb.) did not perform as well as the ones planted on 23 Feb., this likely

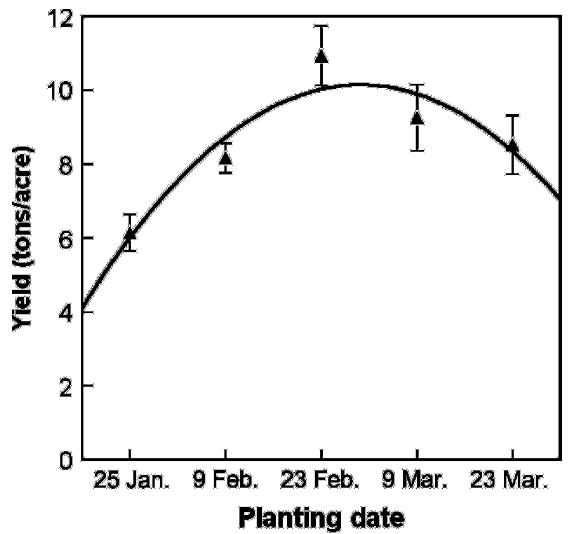

Fig. 1. Effects of planting dates on the yield of intercropped cucumber with strawberry. Regression equation is $\mathbf{y}=$ $6.02+0.2288 x-0.0032 x^{2} ; r^{2}=0.87$, where $\mathrm{x}=$ planting date and $\mathrm{y}=$ cucumber yield. Vertical bars represent the $\mathrm{se} ; \mathrm{l}$ ton/acre $=2.2417 \mathrm{t} \cdot \mathrm{ha}^{-1}$.

indicated that cucumber growth and flowering was also susceptible to cold temperatures at or near freezing during those 2 months.

Warmer temperatures seemed to favor summer squash yield, with higher yields when planted on 23 Feb. or later (Fig. 2). Planting the crop as early as 25 Jan. (3.2 tons/ acre) significantly reduced yields by $33 \%$ in comparison with those obtained in plots planted on $23 \mathrm{Feb}$. (4.8 tons/acre). There were no significant yield differences among the 23 Feb., 9 Mar., and 23 March planting dates, ranging between 4.8 and 5.2 tons/acre. Summer squash thrived in the warmer part of the season (May and early June), when minimum and maximum temperatures were $\geq 50{ }^{\circ} \mathrm{F}$ and $\leq 98{ }^{\circ} \mathrm{F}$, respectively. Therefore, it is likely that summer squash growth and fruit

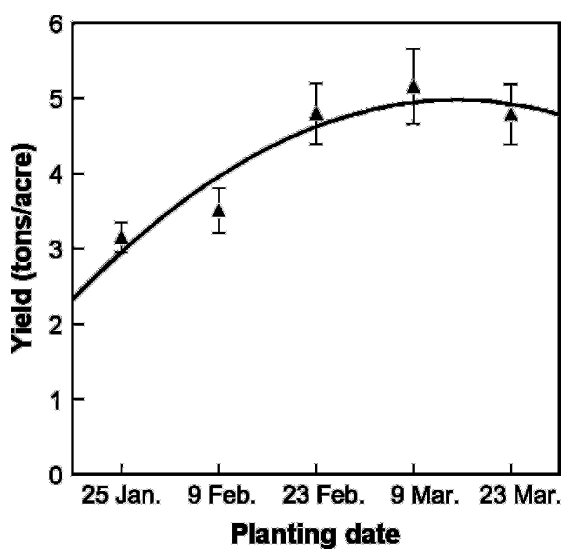

Fig. 2. Effects of planting dates on the yield of intercropped summer squash with strawberry. Regression equation is $\mathrm{y}=2.95+0.0784 \mathrm{x}-0.0008 \mathrm{x}^{2} ; \mathrm{r}^{2}=$ 0.81 , where $\mathrm{x}=$ planting date and $\mathrm{y}=$ summer squash yield. Vertical bars represent the SE; 1 ton/acre $=2.2417$ t. ha ${ }^{-1}$.

setting is affected more by low temperatures in February and March than by the warmer weather afterward.

The opposite response was observed with muskmelon, where yields were significantly reduced as temperatures increased (Fig. 3). The largest production was measured when the crop was planted on 25 Jan. (19.6 tons/acre), declining sharply afterward. Muskmelon yields were below 10 tons/acre when planted on 9 March or later. The sharp muskmelon yield decrease during late plantings can be explained by the exposure of reproductive vines to excessively high temperatures during late May and June of those plots planted from 23 Feb. to 23 Mar., likely causing low pollination or flower abortion.

Planting dates caused very distinctive responses of the three cucurbit species tested in this study. Because there were no variations on strawberry canopy diameters, it is unlikely that there were significant changes in light competition throughout the cucurbit seasons. Air temperatures seemed to play a major role in these yield responses. Cucumber and summer squash were favored when planted under warmer temperatures than muskmelon, which thrives under earlier plantings during cooler weather. It is worth noting that the muskmelon growing season is at least $25 \mathrm{~d}$ longer than that for cucumber and summer squash, which exposes 


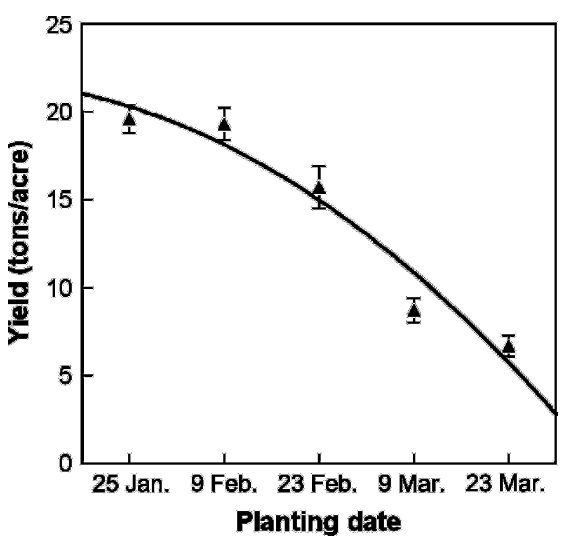

Fig. 3. Effects of planting dates on the yield of intercropped muskmelon with strawberry. Regression equation is $\mathbf{y}=$ $20.31-0.1126 \mathrm{x}-0.0022 \mathrm{x}^{2} ; \mathrm{r}^{2}=0.91$, where $\mathrm{x}=$ planting date and $\mathrm{y}=$ muskmelon yield. Vertical bars represent the $\mathrm{SE} ; 1$ ton $/ \mathrm{acre}=\mathbf{2 . 2 4 1 7}$ t.ha ${ }^{-1}$.

reproductive vines to excessively high temperatures $\left(>90{ }^{\circ} \mathrm{F}\right)$ in May and June, potentially reducing fruit setting. These results are consistent with those found by Sedgley and Buttrose (1978) and Wien (2002) in watermelon, Rylski (1974) in summer squash, and Cantliffe (1981) in cucumbers, which show the stressful effect of high temperatures on pollination, flower development, and fruiting. Thus, growers would benefit by planting muskmelon early. There are no reports on the relative effect of temperature on cucumber, summer squash, and muskmelon flowering and fruit setting. However, muskmelon might be more tolerant then the other two cucurbit species to early cool temperatures.
In summary, the best dates for intercropping with strawberry in west-central Florida were 23 Feb. for cucumber, between $23 \mathrm{Feb}$. and 23 March for summer squash, and between 25 Jan. and 9 Feb. for muskmelon. It is unclear how much competition for light, space, and nutrients strawberry plants had on the cucurbits. However, strawberry is the main cash crop for growers and cucurbits are considered the secondary commodities, thus it is beneficial for growers to know that intercropping cucumber, summer squash, and muskmelon at or after 25 Jan. does not affect the main crop.

\section{Literature cited}

Brown, J.E., W.E. Splittstoesser, and J.M. Gerber. 1985. Production and economic returns of three vegetable doublecropping systems. J. Amer. Soc. Hort. Sci. 110:414-417.

Cantliffe, D.J. 1981. Alteration of sex expression in cucumber due to changes in temperature, light intensity and photoperiod. J. Amer. Soc. Hort. Sci. 106:133136.

Coolman, R.M. and G.D. Hoyt. 1993 Increasing sustainability by intercropping. HortTechnology 3:309-312.

Duval, J.R. 2005. Relay-intercropping does not reduce strawberry yield in an annual-hill production system. HortTechnology 15:907-908.

Karlidag, H. and E. Yildirim. 2007. The effects of nitrogen fertilization on intercropped strawberry and broad bean. J. Sustainable Agr. 29:61-74.

Nitsch, J.P., E.B. Kurtz, Jr., J.L. Liverman, and F.W. Went. 1952. The develop- ment of sex expression in cucurbit flowers. Amer. J. Bot. 39:32-43.

Peres, N.A., J.F. Price, W.M. Stall, C.K. Chandler, S.M. Olson, T.G. Taylor, S.A. Smith, and E.H. Simonne. 2006. Strawberry production in Florida, p. 375-382. In: S.O. Olson and E.H. Simonne (eds.). Vegetable production handbook for Florida, 2006-2007. Institute of Food and Agricultural Sciences, University of Florida, Gainesville.

Poling, E.B. and W.J. Lamont. 1991. A partial economic analysis of doublecropping annual hill plastic mulch strawberries with muskmelons. Adv. Strawberry Production 10:60-62.

Rylski, I. 1974. Effects of season on parthenocarpic and fertilized summer squash (Cucumis pepo L.). Experimental Agr. 10:39-44.

Sedgley, M. and M.S. Buttrose. 1978. Some effects of light intensity, daylength and temperature on flowering and pollen tube growth in the watermelon (Citrullus lanatus). Ann. Bot. (Lond.) 42:609-616.

Simms, T., J. Bantle, W. Hrycan, and D. Waterer. 2006. Potential to double crop vegetables on plastic mulch. Can. J. Plant Sci. 86:1435.

Theunissen, J. 1997. Intercropping in field vegetables as an approach to sustainable horticulture. Outlook Agr. 26:9599

U.S. Department of Agriculture. 2008. Vegetables: 2007 summary. 2 May 2008. <http://usda.mannlib.cornell.edu/ usda/current/VegeSumm/VegeSumm01-25-2008.pdf>.

Wien, H.C. 2002. The cucurbits: Cucumber, melon, squash and pumpkin, p. 345386. In: H.C. Wien (ed.). The physiology of vegetable crops. CABI, New York. 